\title{
MENEMUKAN KEMBALI MAKNA TOBAT KRISTIANI DARI TATA PERAYAAN TOBAT
}

\author{
Petrus Canisius Edi Laksito \\ STKIP Widya Yuwana \\ nanglik@gmail.com
}

\begin{abstract}
Sacrament of Penance is of great importance for the formation of the faithful in their path to holiness after Baptism. This Sacrament is intended as an instrument for theircontinual cleansing and sanctification as the disciples of Christ, so that they can bear many fruits in their life. This work of sanctification is a key element in their Christian life due to the power of sins which defiles them as the members of Christ. This paper wants to explore the meaning of the Sacrament of Penance in the work of sanctification of the faithful from the liturgical document Ordo Paenitentiae (1973) and the subsequent documents on it. At the end of the discussion, it wants to bring some pastoral consequences related to the practice of this Sacrament in the context of the life of the faithful in the Diocese of Surabaya.
\end{abstract}

Keywords: Sacrament of Penance, Rite of Penance, Continual Sanctification

\section{PENDAHULUAN}

Setelah membahas Sakramen-sakramen Inisiasi dalam kaitannya dengan kemuridan pada nomor A.3., A.4. dan A.5., serta arti ketiga sakramen tersebut bagi Panggilan Umum Murid-murid Kristus Kepada Kekudusan di nomor A.6., ARAH DASAR KEUSKUPAN SURABAYA Tahun 2020-2030, dalam "Penjelasan Butir-butir Arah Dasar" nomor A.7. berbicara mengenai Sakramen Pengakuan Dosa. Sakramen ini dimaksudkan sebagai sarana "pembersihan atau pengudusan" bagi para murid Kristus, agar "sebagai ranting dari pokok anggur sejati dapat semakin berbuah banyak”. Dalam perumpamaan tentang pokok anggur dan ranting-rantingnya itu, "pembersihan atau pengudusan” dikaitkan dengan kekuatan dosa "yang mengotori, menghalangi bahkan memutuskan hubungan pokok anggur dan ranting-rantingnya sehingga tidak menghasilkan buah”. Sementara, dengan Sakramen Pengakuan Dosa, para murid Kristus diberi kekuatan rohani "untuk bertekun dan setia di jalan kemuridan” (Keuskupan Surabaya, 2019: 13).

Nomor A.7. sendiri diberi judul "Pengudusan Terus-menerus Melalui Pertobatan”. Judul ini mengisyaratkan bahwa panggilan umum kepada kekudusan, yang berlaku bagi para imam, religius dan awam, merupakan upaya tiada henti 
yang mengandaikan ketekunan dan kesetiaan. Dengan menjelaskan bahwa Sakramen Pengakuan Dosa merupakan sakramen "pembersihan dan pengudusan”, nomor A.7. bermaksud menegaskan bahwa pembersihan dan pengudusan terusmenerus itu bukanlah hasil usaha manusia yang mengandalkan daya kodrati belaka. Pembersihan dan pengudusan sepanjang hari itu membutuhkan rahmat Allah yang bekerja dalam diri mereka melalui Sakramen Pengakuan Dosa. Gambaran tentang pokok anggur dan ranting-rantingnya dipilih untuk menjelaskan pentingnya Sakramen Pengakuan Dosa, dan untuk menegaskan bahwa dalam hidup Kristiani, Sakramen ini tidak bisa dipandang dengan sebelah mata. Dengan sakramen inilah murid-murid tinggal di dalam Kristus. Tanpa sakramen ini, hidup mereka akan menjadi kering, karena tak lagi bersatu dalam kebersihan dan kekudusan bersama dengan Dia. "Barangsiapa tidak tinggal di dalam Aku, ia dibuang ke luar seperti ranting dan menjadi kering, dan kemudian dikumpulkan orang dan dicampakkan ke dalam api lalu dibakar” (Yoh 15:6).

Untuk menggali arti penting Sakramen ini bagi pengudusan terus-menerus para murid menuju kesempurnaan hidup Kristiani, penulis bermaksud menggali makna tobat dari buku "Tata Perayaan Tobat" atau Ordo Paenitentiae (1973) dan dokumen Gereja yang belakangan ini membahasnya. Terakhir, tahun 2015, Kongregasi Untuk Ibadat Ilahi dan Disiplin Sakramen-sakramen mengeluarkan artikelberjudul "Menemukan Kembali Ritus Tobat” (Rediscovering the Rite of Penance). Sebelum itu, Paus Yohanes Paulus II, di tahun 2002, mengeluarkan Surat Apostolik dalam bentuk Motu Proprio berjudul Misericordia Dei, untuk membahas aspek-aspek tertentu perayaan Sakramen Tobat. Agak jauh sebelumnya, tahun 1984, paus yang sama mengeluarkan Seruan Apostolik postsinodal Reconciliatio et Paenitentia tentang rekonsiliasi dan tobat dalam perutusan Gereja dewasa ini. Khususnya, dua dokumen pertama muncul dari konteks kesadaran akan kerahiman Allah menyongsong milenium ke-3 pada Tahun Yubileum Agung 2000, serta Yubileum Luarbiasa Kerahiman pada tahun 2015-2016.

Untuk itu, pertama-tama di sini akan digali konteks sejarah munculnya dokumen Ordo Paenitentiae. Kemudian, disajikan pokok-pokok teologis yang terkandung pada dokumen tersebut, khususnya yang terdapat dalam bagian Catatan pengantar (Praenotanda). Selanjutnya perhatian diberikan pada 2 dokumen yang belakangan ini mengkaji atau mengangkat kembali perayaan Sakramen Tobat ke dalam khasanah Magisterium, yaitu Surat Apostolik Misericordia Dei oleh Paus Yohanes Paulus II tahun 2002 dan artikel dalam Jurnal Notitiae dari Kongregasi Ibadat Ilahi dan Disiplin Sakramen-sakramen berjudul Rediscovering the Rite of Penance tahun 2015. Pada bagian akhir tulisan ini akan ditarik kesimpulan dalam rangka pastoral Sakramen Tobat, dalam kaitan dengan pembentukan semangat kemuridan Kristiani yang dikehendaki oleh Ardas. 


\section{KONTEKS MUNCULNYA ORDO PAENITENTIAE}

Konsili Vatikan II menghendaki adanya pembaruan di bidang liturgi. Konstitusi Liturgi Sacrosanctum Concilium (1962) memberikan arahan singkat tentang Sakramen Tobat: "Upacara dan rumus untuk Sakramen Tobat hendaknya ditinjau kembali sedemikian rupa, sehingga hakekat dan buah Sakramen terungkap secara lebih jelas” (SC 72). Dokumen persiapan Konsili sendiri tidak berbicara tentang pembaruan Sakramen Tobat, namun muncul harapan agar ada rumusan yang lebih jelas mengenai efek Sakramen ini. Selama persidangan, muncul harapan agar karakter sosial dan komunal dosa dan tobat, yang terdapat pada upacara tobat zaman dulu, lebih ditampakkan. Usulan yang cukup inovatif muncul dari uskup-uskup Kolombia mengenai absolusi umum tanpa didahului pengakuan, pada kasus-kasus tertentu. Dengan demikian setidaknya muncul perhatian pada hakikat dan efek sakramen, khususnya dalam dimensi sosial dan komunal. Secara eksplisit dimensi komunal-eklesial kelak dinyatakan dalam Konsitusi Dogmatis Lumen Gentium (1964): “Mereka yang menerima Sakramen Tobat memperoleh pengampunan dari belas-kasihan Allah atas penghinaan mereka terhadap-Nya; sekaligus mereka didamaikan oleh Gereja, yang telah mereka lukai dengan berdosa, dan yang membantu pertobatan mereka dengan cinta kasih, teladan dan doa-doanya” (LG 11) (Dallen, 1991: 205-207).

Meskipun kehendak Konsili sudah dinyatakan pada tahun 1962, tapi dalam kenyataannya diperlukan waktu 10 tahun untuk terbitnya Tata Perayaan Tobat yang baru. Panitia pertama kali dibentuk pada akhir tahun 1966, diketuai oleh J. Lecuyer, C.S.Sp (Lateran, Roma), dengan anggota Franz Heggen (Roermond), Franz Nikolasch (Salzburg), Zoltan Alszeghy, S.J. (Gregoriana, Roma), Paul Anciaux (Malines), C. Florestan (Madrid), Alfons Kirchgässner (Frankfurt), Louis Ligier, S.J. (Oriental Institute, Roma), Karl Rahner, S.J. (Münster), dan Cyrille Vogel (Strasbourg). Panitia bertanggung jawab kepada Consilium, yaitu Dewan atau Komisi Penerapan Konstitusi Liturgi. Untuk pembaruan Ritus, Panitia menyepakati 4 kriteria, yaitu agar Ritus mengungkapkan dengan lebih jelas: 1. hakikat dosa sebagai penghinaan (offense) terhadap Allah dan Gereja; 2. pendamaian serentak dengan Allah dan Gereja; 3. melalui cinta kasih, teladan dan doa-doa, seluruh Gereja bekerjasama dengan usaha tobat pendosa; 4. nilai Sakramen Tobat dalam meneguhkan kehidupan Kristiani. Garis besar ini disetujui oleh Consilium. Ritus yang baru hendaknya mengungkapkan dimensi komunal, dengan menyediakan perayaan komunal dan perayaan dengan absolusi umum manakala hal itu diizinkan (Dallen, 1991: 209-211).

Setelah bagian pengantar, yang memberikan pendasaran teologis, pastoral dan kanonik, diterima oleh Consilium pada Oktober 1968, panitia diminta memberikan laporan tentang kemungkinan aneka rumusan absolusi. Namun berbagai rumusan ini rupanya justru menimbulkan perbedaan pendapat antara 
Consilium dan panitia, serta di antara Consilium sendiri, yang suaranya terbagi dua secara hampir berimbang. Laporan yang diminta oleh Consilium sendiri telah diserahkan kepada mereka oleh panitia. Di situ argumen pro dan kontra dikaji, dan alternatif-alternatif direkomendasikan berdasarkan preseden masa lampau, praktik di Gereja Timur, serta manfaat pastoral dan teologisnya. Sementara pekerjaan belum selesai, pada tanggal 8 Mei 1969, Consilium dipecah menjadi Kongregasi untuk Ibadat Ilahi dan Kongregasi untuk Perkara Orang-orang Kudus. Maka persoalannya sekarang berada di bawah Kongregasi untuk Ibadat Ilahi. Diskusi dalam Kongregasi berlangsung panas. Dengan selisih suara sedikit, diputuskan untuk memberi kemungkinan lebih dari satu rumusan. Panitia menyerahkan hasil akhir dan draft pada akhir tahun 1969. Namun tidak jelas apa yang terjadi kemudian (Dallen, 1991: 212-213).

Rupanya Kongregasi untuk Ajaran Iman, yang bertugas mengevaluasi ortodoksi ritus-ritus yang diusulkan, mempunyai keberatan, dan menginginkan agar rumusan absolusi mengacu pada rumusan Konsili Trente. Meskipun pada masa itu diterbitkan berbagai macam ritus baru, namun tidak ada kabar tentang Ritus Tobat. Ini menggambarkan adanya ketegangan antara Kongregasi untuk Ibadat Ilahi dan Kongregasi untuk Ajaran Iman terkait Ritus Tobat. Setelah 2 tahun tanpa berita, pada akhir 1971, terbit suatu komentar terinci mengenai draft Ritus, dengan nada positif. Tanggal 16 Juni 1972, Kongregasi untuk Ajaran Iman menerbitkan Norma-norma Pastoral tentang Absolusi Umum. Norma-norma ini memberikan tanggapan negatif atas persoalan-persoalan doktrinal yang muncul dari draft Ritus, praktik absolusi umum yang berkembang, dan pengakuan atas praktik tersebut oleh beberapa hirarki di tingkat nasional. Norma-norma itu memperluas peluang penggunaan absolusi umum, tetapi juga memberikan batasbatas untuk pembaruan. Berdasarkan keputusan itu, harus dibuat langkah baru (Dallen, 1991: 213-214).

Pada bulan itu juga dibentuk panitia baru, dipimpin oleh P. Journel (Paris), dengan anggota Franco Sottocornola, S.X. (Parma), Antonio Gracia (Zaragoza), P. Vinsentin, O.S.B. (Padua), Hans Bernhard Meyer, S.J. (London) dan G. Pasqualetti, I.M.C. (Kongregasi Ibadat Ilahi). Tim ini secara akademis kurang dikenal. Mereka lebih memiliki orientasi pastoral. Tugas panitia baru ini adalah menyesuaikan draft yang disusun oleh panitia lama dengan Norma-norma Pastoral, melengkapi pengantar sesuai dengan gaya ritus-ritus baru yang lain, dan memperkaya ritus-ritus itu sendiri. Tugas ini dipermudah karena pengalaman mempersiapkan ritus-ritus baru, dan karena adanya keputusan untuk hanya memberikan satu rumusan absolusi, yang memuat rumusan yang berlaku selama ini. Namun, hasil akhir panitia ini tidak banyak sesuai dengan hasil akhir panitia pertama. Perubahan struktur paling menyolok adalah sekarang ditambahkan Perayaan Sabda dalam ritus tobat bagi individu. Draft diserahkan kepada para 
konsultor Kongregasi Ibadat Ilahi, dan kepada sidang pleno Kongregasi pada tanggal 22 November 1972 (Dallen, 1991: 214-215).

Setelah direvisi, tanggal 30 November 1972 draft dikirimkan kepada Kongregasi untuk Ajaran Iman, Kongregasi untuk Sakramen-sakramen, Kongregasi Imam dan Kongregasi untuk Penginjilan Bangsa-bangsa. Amat banyak masukan diberikan. Sebagai kompromi, tobat (penance) dan pendamaian (reconciliation) sama-sama dipakai untuk merujuk pada sakramen ini. Doa Bapa Kami diganti dengan doa tobat (act of contrition) dalam ritus individual, dan rumusan "Aku melepaskanmu" (Ego te absolvo; I absolve you) tetap dipertahankan. Banyak koreksi dari Kongregasi untuk Ajaran Iman disertakan. Setelah mendapatkan pengakuan (approval) dari Kongregasi untuk Ibadat Ilahi dan wakil-wakil dari berbagai bidang, draft dikirimkan ke para ketua konferensi uskup-uskup dan ahli-ahli lainnya. Berdasarkan masukan dari luar Roma, makin terlihat tajam perbedaan antara kecenderungan merujuk pada Konsili Trente di satu sisi dan keinginan untuk secara pastoral lebih peka pada tradisi yang lebih luas di sisi lain. Bagaimanapun, posisi Kongregasi untuk Ajaran Iman akhirnya tetap menjadi penentunya. Tanggal 29 November 1973 Paus Paulus VI memberikan pengakuan pada teks final, dan pada 2 Desember 1973 Kongregasi untuk Ibadat Ilahi mempromulgasikannya sebagai dokumen resmi (Dallen, 1991: 215).

\section{ISI TEOLOGIS DAN RITUAL ORDO PAENITENTIAE}

Ordo Paenitentiae (dalam bahasa Inggris disebut The Rite of Penance; dan dalam bahasa Indonesia “Tata Perayaan Tobat”) terdiri dari Catatan Pengantar (Praenotanda), serta 4 bab dan 3 apendiks. Catatan Pengantar merupakan bagian amat penting karena memberikan seluruh pendasaran dan penjelasan tentang Tata Perayaan Tobat yang ditampilkan dalam beberapa formula. Pertama-tama dijelaskan pengertian tobat dan pelayanan tobat (OP 1-11), selanjutnya cara Sakramen Tobat dirayakan (OP 12-40). Bab I menyajikan tata perayaan tobat bagi peniten secara individual (OP 41-47); Bab II memuat tata perayaan tobat untuk beberapa peniten dengan pengakuan dan absolusi individual (OP 48-59); Bab III berisi tata perayaan tobat untuk beberapa peniten dengan pengakuan dan absolusi umum (OP 60-66). Bab IV menampilkan aneka teks untuk digunakan dalam berbagai perayaan, baik dengan satu ataupun dengan banyak peniten (OP 67-214). Apendiks pertama menghadirkan rumusan-rumusan untuk memberikan absolusi dari sensura dan dispensasi dari iregularitas. Apendiks kedua memuat hal-hal khusus untuk perayaan tobat pada masa Prapaskah, Adven dan perayaan-perayaan tobat yang umum, serta contoh untuk perayaan tobat khusus bagi anak-anak, remaja dan orang tua. Apendiks ketiga berisi sebuah skema atau model untuk 
pemeriksaan batin. Untuk membahas isi teologis, ritual dan pastoral Ordo Paenitentiae pada bagian ini, cukup dirujuk Catatan Pengantar (Praenotanda).

Catatan Pengantar dibuka dengan "misteri pendamaian dalam sejarah keselamatan”, yaitu kehendak Bapa untuk menyatakan kerahiman-Nya dengan mendamaikan dunia dengan diri-Nya dalam Kristus melalui darah-Nya yang tertumpah di salib. Kristus mewartakan pertobatan sebagai sikap dasar menyambut kedatangan Kerajaan Allah. Warta ini telah dirintis oleh para nabi, dan berpuncak pada Yohanes Pembaptis, yang mewartakan baptis pertobatan untuk penghapusan dosa (Mrk 1:4). Yesus sendiri, selain mewartakan pertobatan, juga menerima para pendosa untuk mendamaikan mereka dengan Bapa. Ia menyembuhkan orang sakit, dan lewat tindakan itu menegaskan kuasa-Nya untuk menghapus dosa. Dengan kurban Perjanjian Baru Ia mempersembahkan kurban penghapusan dosa dalam darah-Nya, dan setelah kebangkitan-Nya Ia mengutus Roh Kudus kepada para Rasul agar mereka melaksanakan kuasa untuk melepas dosa ataupun untuk menyatakan bahwa dosa orang tetap ada. Dengan kuasa itu mereka diutus-Nya mewartakan pertobatan dan penghapusan dosa dalam namaNya kepada semua bangsa. Dengan mandat yang diterima oleh para Rasul itu Gereja mengemban tugas untuk mengantar manusia kepada pertobatan, dan untuk merayakan kemenangan Kristus atas dosa dalam diri orang-orang yang bertobat. Kuasa Yesus demi pertobatan dan penghapusan dosa ini terlaksana dalam Sakramen Baptis dan Ekaristi, namun secara istimewa dinyatakan dalam Sakramen Tobat. Dengan Sakramen ini umat beriman, yang telah disucikan dari dosa dalam Baptis sebagai pembasuhan pertama, dengan rahmat yang dibaharui, didamaikan kembali dengan Allah. Seperti dikatakan oleh St. Ambrosius, Gereja "memiliki air dan air mata; air Baptis dan air mata Tobat” (et aquam habet et lacrimas: aquam baptismatis, lacrimas paenitentiae) (Sacra Congregatio, 1974: 9-10).

Gereja sendiri kudus karena Kristus “mengasihi Gereja dan menyerahkan diri-Nya sendiri baginya, untuk menguduskannya” (Ef 5:25-26). Namun di pangkuan Gereja juga terdapat para pendosa, sehingga pada saat yang sama harus senantiasa dimurnikan dengan pertobatan dan pembaruan diri. Pertobatan terusmenerus ini dilakukan dengan berbagai cara, antara lain melalui keikutsertaan dalam kesengsaraan Kristus, dengan karya cintakasih dan kerahiman, dengan pertobatan setiap hari seturut Injil Kristus, agar dengan demikian Gereja menjadi tanda pertobatan di dunia kepada Allah. Melalui perayaan tobat, pewartaan sabda Allah, doa dan unsur-unsur pertobatan dalam perayaan Ekaristi, para pendosa melalui perayaan liturgi memohon ampun kepada Allah dan sesama. Tetapi terutama dalam Sakramen Tobat umat beriman memperoleh pengampunan yang berasal dari kerahiman Allah atas penghinaan kepada-Nya, dan pada saat yang sama diperdamaikan dengan Gereja, yang mereka lukai karena melakukan dosa. 
Gereja, dengan cinta kasih, teladan dan doa-doa berkarya demi pertobatan mereka. Dengan pertobatan, pendosa mengarahkan diri kembali kepada Bapa yang lebih dahulu mengasihi kita, kepada Kristus yang telah menyerahkan diriNya bagi kita, dan kepada Roh Kudus yang dicurahkan secara melimpah kepada kita. Sekaligus dengan pertobatan manusia diperdamaikan satu sama lain sebagai saudara, untuk mengusahakan keadilan dan damai di dunia dengan semua orang yang berkehendak baik (Sacra Congregatio, 1974: 10-12).

Setelah membahas kedudukan tobat dalam Gereja, Praenotanda mengupas pelaksanaan Sakramen Tobat dan bagian-bagiannya. Secara keseluruhan, prosesnya digambarkan sebagai berikut: Murid Kristus, setelah terjadi dosa, digerakkan oleh Roh Kudus, datang ke Sakramen Tobat. Sebelum semua dilakukan, ia haruslah mengarahkan diri dengan segenap hati kepada Allah. Pertobatan hati yang mendalam ini (intima cordis conversio), yang disertai dengan penyesalan atas dosa dan niat akan hidup yang baru, selanjutnya ia ungkapkan melalui pengakuan yang dibuat kepada Gereja, dan melalui denda dosa serta perbaikan hidup. Baginya Allah sungguh mengaruniakan penghapusan dosa-dosa melalui Gereja, yang dilaksanakan oleh pelayanan para imam (Congregation, 1974: 12).

Dari gambaran di atas terlihat bahwa pertobatan pertama-tama adalah gerakan batin manusia yang muncul atas prakarsa Roh Kudus, yang menyadarkannya akan arah hidup yang harus diperbaiki, yaitu kini harus tertuju kepada Allah semata. Ditekankan bahwa pertobatan bersifat batiniah, menyangkut kedalaman hati manusia (intima cordis conversio).

Dalam bingkai menyeluruh tentang Sakramen ini, selanjutnya Praenotanda menguraikan 4 unsur yang membentuk kesatuan sakramental. Pertama-tama yang berasal dari pihak peniten, yaitu penyesalan (contritio), pengakuan (confessio), dan denda dosa (satisfactio). Selanjutnya dari pihak imam sebagai pelayan Sakramen, yaitu pelepasan dari dosa (absolutio). Dengan Sakramen Tobat, "Bapa menerima putera yang pulang kembali kepada-Nya, Kristus memanggul domba yang hilang di bahu-Nya dan membawanya kembali ke kawanan, dan Roh Kudus menyucikan bait-Nya kembali dan tinggal secara lebih penuh”. Pada akhirnya, melalui partisipasi dalam meja Tuhan yang dibaharui dan yang lebih meriah, terjadi sukacita besar dalam perjamuan Gereja, berkat sang putera yang kini pulang kembali dari negeri yang jauh (Sacra Congregatio, 1974: 12-13).

Seperti pengobatan, Sakramen Tobat perlu dan berguna seturut keadaan dosa umat beriman. Bagi yang telah dijauhkan dari persekutuan kasih Allah karena dosa berat, Sakramen Tobat menjadi panggilan untuk kembali kepada kehidupan yang telah mereka tinggalkan. Bagi yang berdosa ringan, Sakramen Tobat menjadi kesempatan untuk semakin masuk ke dalam kebebasan penuh 
anak-anak Allah. Kemudian, agar dapat menerima “obat sakramental” yang tepat dan sesuai bagi keselamatannya, peniten di hadapan kerahiman Allah haruslah mengakukan kepada imam "semua dan setiap dosa berat" (omnia et singula peccata gravia) sejauh dapat diingatnya. Namun karena Sakramen ini juga sangat berguna bagi dosa-dosa ringan, maka perlu sering dimanfaatkan. Bukan sekedar sebagai pengulangan ritual atau latihan yang bersifat psikologis belaka, melainkan sebagai upaya tekun untuk menyempurnakan rahmat Baptis yang telah diterima. Seperti halnya kita ambil bagian dalam matiraga Kristus di dalam tubuh kita, kiranya melalui Sakramen Tobat ini hidup Kristus dari hari ke hari semakin terwujud di dalam diri kita. Dengan cara pandang ini, ketika mengakukan dosadosa ringan, umat beriman berupaya agar dengan tobat yang semakin dalam ia semakin menyerupai Kristus dan semakin peka dalam mendengarkan suara Roh Kudus. Maka agar sungguh bermanfaat bagi umat beriman, Sakramen ini perlu ditempatkan sebagai akar dalam seluruh hidup, yang menggerakkan mereka untuk semakin bersemangat dalam melayani Allah dan sesama (Sacra Congregatio, 1974: 13-14).

Selanjutnya, Praenotanda membahas tugas dan pelayan Sakramen Tobat. Digarisbawahi bahwa seluruh Gereja, sebagai umat yang imami, dengan aneka cara melaksanakan tugas pendamaian ini. Melalui pewartaan sabda serta perhatian dan keprihatian keibuannya Gereja menjadi pengantara bagi pendosa untuk menyadari dosa mereka dan mengakukannya di hadapan kerahiman Allah. Gereja menjadi sarana istimewa pertobatan dan pelepasan dosa lewat tugas yang dipercayakan Kristus kepada para Rasul dan uskup pengganti mereka. Para imam, khususnya yang memiliki fakultas (hak) untuk memberikan absolusi berdasarkan Hukum Kanonik, ambil bagian dalam tugas ini dalam kesatuan dengan uskup. Juga imam siapapun, dalam bahaya kematian dapat dengan sah dan licit (sesuai ketentuan) melayani Sakrmen ini. Dalam melakukan tugasnya, para imam harus memberikan pengobatan yang tepat bagi penyembuhan jiwa, dengan bersikap sebagai hakim yang bijaksana, dengan pemahaman dan kehati-hatian, dengan upaya tekun, di bawah bimbingan Magisterium Gereja, sambil menyatukan diri dalam doa kepada Allah. Sikap ini penting karena pembedaan roh sebagai pengetahuan mendalam tentang karya Allah dalam hati manusia, merupakan rahmat Roh Kudus dan buah cinta kasih. Imam hendaknya siap sedia menerima umat beriman yang datang untuk mengaku dosa. Dengan menjalankan tugas kebapaan, mereka menyingkapkan hati Bapa kepada manusia, dan membawa citra Kristus Gembala kepada mereka. Dengan menjaga rahasia peniten, imam menjaga meterai sakramental. Sementara itu peniten ambil bagian lewat tindakan-tindakan sesuai ritus, dan disempurnakan dengan kata-kata absolusi oleh imam. Dengan cara ini ia mengalami dan mewartakan kerahiman Allah dalam hidupnya. Sembari 
membaharui dirinya sendiri secara terus-menerus ia merayakan liturgi Gereja dalam persatuan dengan imam (Sacra Congregatio, 1974: 14-16).

Kemudian, Praenotanda menjelaskan Tata Perayaan Tobat, yang dapat dilaksanakan dalam 3 bentuk, yaitu untuk peniten secara individual (Sacra Congregatio, 1974: 16-18), untuk banyak peniten dengan pengakuan dan absolusi individual (Sacra Congregatio, 1974: 18-20), dan untuk banyak peniten dengan pengakuan dan absolusi umum (Sacra Congregatio, 1974: 21-23).

Pada bentuk pertama, peniten secara pribadi datang kepada imam. Setelah pengucapan salam, ia membuat tanda salib. Setelah sabda Allah dibacakan, peniten mengakukan dosa-dosa, dan imam memberikan nasihat untuk mengusahakan pembaharuan hidupnya. Setelah imam menyampaikan denda dosa, peniten menyampaikan doa kepada Allah sebagai pernyataan tobat. Lalu imam memberikan absolusi dengan rumusan inti: "Aku melepas engkau dari dosadosamu, dalam nama Bapa, dan Putera, dan Roh Kudus”, sembari saat itu juga membuat tanda salib di atas peniten. Rumusan ini menyatakan bahwa peniten diperdamaikan berkat kerahiman Allah, dalam suatu pendamaian yang dihasilkan oleh misteri Paskah Kristus dan karena terlaksananya tugas Roh Kudus dalam pengampunan dosa. Sementara itu, dimensi gerejawi Sakramen ini juga terungkap, karena pendamaian dengan Allah terjadi melalui pelayanan Gereja. Setelah pengampunan dosa diterima, peniten mengucapkan syukur dan pujian kepada Allah secara singkat, kemudian imam melepas peniten meninggalkan tempat pengakuan. Dengan demikian pengakuan selesai. Sesuai kebutuhan pastoral, imam dapat mempersingkat Tata Perayaan ini, tanpa menghilangkan unsur-unsur pokok, yaitu: pengakuan dosa dan penerimaan denda dosa, ajakan untuk menyesali dosa, rumusan absolusi dan rumusan pengutusan. Tetapi jika didesak oleh bahaya kematian, imam cukup mengatakan kata-kata pokok dalam rumusan absolusi, yaitu: “Aku melepas engkau dari dosa-dosamu, dalam nama Bapa, dan Putera, dan Roh Kudus”.

Bentuk kedua diadakan dengan banyak peniten. Sakramen Tobat didahului ibadat Sabda sebagai persiapan. Jika memungkinkan, perayaan dihadiri sejumlah imam untuk mendengarkan pengakuan umat beriman dan memberikan absolusi kepada mereka. Umat yang mengakukan dosanya di waktu yang lain juga dapat ikut serta dalam ibadat ini. Perayaan bersama ini mengungkapkan hakikat gerejawi pertobatan secara lebih jelas. Ibadat dibuka dengan lagu yang sesuai, lalu imam pemimpin ibadat mengucap salam dan memberikan pengantar, dan setelahnya memanjatkan doa pembukaan. Setelah sabda Allah dibacakan, homili, yang mengantar pada pemeriksaan batin disampaikan. Penting untuk ditekankan: kerahiman Allah tanpa batas yang melampaui kelemahan kita, perlunya pertobatan batin secara tulus, aspek sosial rahmat dan dosa karena tindakan satu orang melukai seluruh Tubuh, serta tindakan silih atau denda dosa yang memiliki 
kekuatan karena tindakan silih Kristus, yang hendaknya menumbuhkan cinta kasih yang lebih besar kepada Allah dan sesama. Setelah pemeriksaan batin, umat dipersilakan berlutut atau membungkuk dan menyatakan pengakuan dengan rumus umum (misalnya: “Saya mengaku”). Menyusul doa-doa yang mengungkapkan pertobatan, diakhiri dengan Bapa Kami yang tak boleh ditiadakan. Setelah itu imam menuju tempat pengakuan masing-masing. Peniten dipersilakan menuju ke tempat imam dan mengakukan dosa. Setelah menerima denda, ia menerima absolusi dengan rumusan yang diperuntukkan bagi satu peniten. Setelah semua pengakuan selesai, para imam kembali ke tempat, dan pemimpin mengajak semua hadirin untuk mengucap syukur atas kerahiman Allah. Imam mengakhiri perayaan dengan doa, sambil memuji Allah karena mengasihi umat dengan cintakasih-Nya. Setelah itu imam memberi berkat, dan umat dibubarkan.

Bentuk ketiga yaitu perayaan tobat bagi banyak peniten dengan pengakuan dan absolusi umum. Bagian ini diawali dengan penjelasan disipliner tentang absolusi umum. Pada dasarnya, jika tidak ada ketidakmungkinan fisik dan moral, pengakuan dan absolusi yang individual dan utuh tetap merupakan satu-satunya cara yang biasa untuk pendamaian dengan Allah dan sesama. Tapi bisa jadi, karena hal-hal khusus, memberikan absolusi secara umum bagi banyak umat, tanpa didahului pengakuan individual, diperkenankan atau juga perlu. Dalam bahaya kematian, didesak waktu yang singkat dengan jumlah imam yang tidak mencukupi untuk mendengarkan pengakuan individual bagi banyak umat, absolusi semacam ini dapat diberikan. Hal ini dapat terjadi di tanah misi, juga di tempat lain. Tetapi tidak dapat dilakukan dalam pesta atau ziarah yang besar, yang mengandaikan bahwa banyak bapa pengakuan sesungguhnya bisa hadir. Penilaian tentang kondisi darurat merupakan wewenang Uskup diosesan, dengan mendengarkan beberapa anggota Konferensi Uskup. Agar dapat memberikan absolusi umum sesuai ketentuan, imam harus memperhatikan ketentuan Uskup diosesan. Sedapat mungkin ia menghadap Ordinaris wilayah, dan menjelaskan kepadanya pertimbangan dan absolusi yang diberikan. Tanpa halangan yang amat kuat setelahnya, umat yang telah menerima absolusi umum atas dosa berat harus pergi ke pengakuan individual untuk mengakukan dosa tersebut, jika mungkin pada tahun yang sama. Perayaan tobat dilaksanakan seperti perayaan tobat bagi banyak orang dengan pengakuan dan absolusi individual, dengan beberapa perubahan. Setelah atau dalam homili, umat diajak untuk menyesali tiap dosa, menyatakan keinginan membaharui diri atas segala kesalahan. Setelah itu denda diberikan. Lalu umat yang menginginkan absolusi umum diajak menyatakan penyesalan dengan pengakuan rumus umum (misalnya "Saya mengaku). Lalu doa atau lagu yang menyatakan pertobatan, serta Bapa Kami, entah diucapkan atau dinyanyikan. Lalu imam berdoa mohon rahmat Roh Kudus untuk pengampunan 
dosa, mewartakan kemenangan dari dosa melalui wafat dan kebangkitan Kristus, dan memberikan absolusi sakramental kepada para peniten. Setelah mengajak untuk mendoakan doa syukur, umat diberkati dan dibubarkan.

Selanjutnya, Praenotanda berbicara tentang perayaan-perayaan tobat, pertama-tama dengan menjelaskan ciri khas dan strukturnya, kemudian manfaat dan momentumnya. Strukturnya secara garis besar seperti ibadat Sabda pada umumnya, dan seperti struktur dalam Tata Perayaan Tobat bagi Banyak Peniten. Perayaan-perayaan semacam ini, secara umum bermanfaat mendorong semangat pertobatan dan pemurnian hati, untuk membantu persiapan mengakuan dosa, untuk mendidik anak-anak atau remaja tentang hatinurani yang peka akan dosa dan pembebasan dari dosa melalui Kristus, serta untuk membantu pertobatan para katekumen. Perayaan tobat ini amat berguna, meski tidak disertai dengan kehadiran imam yang memberikan absolusi sakramental, karena membantu tumbuhnya penyesalan yang sempurna yang keluar dari cintakasih. Dengan perayaan ini umat beriman, dalam kerinduan mereka (in voto) akan tobat sakramental di masa depan, dapat memperoleh rahmat Allah (Sacra Congregatio, 1974: 23-34).

Pada akhirnya, Praenotanda memberikan sejumlah catatan tentang penyesuaian-penyesuaian yang dapat dilakukan oleh Konferensi Uskup. Penyesuaian-penyesuaian semacam ini pada dasarnya dapat dibuat dengan mengandaikan aprobasi (pengakuan) dari Tahta Apostolik, untuk diberlakukan di daerah Konferensi Uskup yang bersangkutan (Sacra Congregatio, 1974: 24-25).

\section{MISERICORDIA DEI: NILAI PERSONAL PENGAKUAN DOSA DAN} TOBAT

Hampir 30 tahun setelah Ordo Paenitentiae terbit, Paus Yohanes Paulus II menulis Surat Apostolik tentang beberapa aspek perayaan Sakramen Tobat dalam bentuk motu proprio (atas keinginan sendiri) Misericordia Dei, 7 April 2002. Dengan Motu Proprio ini Paus menegaskan hal-hal pokok dalam perayaan Sakramen Tobat bagi Gereja universal (Paulus II, 2002).

Paus membuka Motu Proprio ini dengan sintesa teologis yang mendasari perutusan Geraja dalam "pelayanan pendamaian” (2 Kor 5:18) melalui Sakramen Baptis dan Tobat. Paus lalu menguraikan situasi pastoral berkenaan dengan Sakramen Tobat sejak krisis "kesadaran akan dosa” (the sense of sin) yang ditengarai oleh Sinode para Uskup tentang Rekonsiliasi dan Tobat, dan yang dibahas dalam Seruan Apostolik Post-Sinodal Reconciliatio et Paenitentia tahun 1984. Meskipun sebab-sebab krisis tersebut belum hilang, namun menurut Paus, Tahun Yubileum 2000 secara istimewa telah ditandai oleh kembalinya Sakramen Tobat, termasuk di antara orang-orang muda. Maka, dalam rangka revitalisasi lebih lanjut Sakramen Tobat ini dalam Gereja, melalui Motu Proprio Paus 
menegaskan dan menetapkan beberapa aspek perayaan Sakramen ini, serta memberlakukannya baik untuk Gereja Ritus Latin maupun bagi Gereja-gereja Katolik Ritus Timur.

Aspek utama yang disorot oleh Misericordia Dei adalah terusiknya struktur dasar Tata Perayaan Sakramen Tobat, khususnya berkenaan dengan dimensi personal dosa dan tobat pada diri peniten atau pengaku dosa, yang berlangsung karena penafsiran yang kurang tepat terhadap "Tata perayaan Tobat" (Ordo Paenitentiae). Dalam penegasan Konsili Trente, berdasar perjalanan sejarah Sakramen ini dari abad ke abad, di samping penilaian dan pelepasan dosa (absolution) dari pihak pelayan Sakramen atas nama Kristus, dari pihak peniten terdapat 3 unsur pokok: penyesalan (contrition), pengakuan (confession) dan silih atau denda (satisfaction). Namun Paus melihat, di beberapa tempat terdapat kecenderungan untuk meninggalkan pengakuan individual dan secara keliru menggunakan absolusi "umum” atau "komunal”. Dalam hal ini, absolusi umum tidak lagi dilihat sebagai suatu sarana luarbiasa (an extraordinary means) yang digunakan dalam situasi-situasi yang sepenuhnya luarbiasa (in wholly exceptional situations). Karena syarat-syarat bagi adanya kebutuhan serius diperluas secara semaunya, kesetiaan pada tata ilahi Sakramen ini dalam praktiknya berkurang, khususnya berkenaan dengan perlunya pengakuan individual. Akibat seriusnya adalah kehidupan rohani umat beriman dan kesucian Gereja dirugikan.

Paus sendiri yakin, di tengah krisis "kesadaran akan dosa” yang melanda budaya zaman ini, panggilan untuk menemukan kembali Kristus sebagai mysterium pietatis ("misteri kekudusan”) menjadi semakin kuat. Melalui Kristus Allah menunjukkan hati-Nya yang berbelarasa, dan mendamaikan diri kita sepenuhnya dengan diri-Nya sendiri. Wajah Kristus inilah yang harus ditemukan kembali lewat Sakramen Tobat, sebagai "sarana biasa untuk memperoleh pengampunan dan penghapusan dosa-dosa serius yang dilakukan setelah Baptis”. Yubileum Agung sendiri ditandai oleh gerakan kembali ke Sakramen Tobat, maka Paus mendorong para uskup dan semua imam untuk mengupayakan revitalisasi Sakramen Pendamaian ini dengan penuh semangat (a vigorous revitalization). Paus memandang penting memberikan perhatian pada "sikap atau kecenderungan batin yang tepat” (the proper interior dispositions) pada umat agar dapat memperoleh rahmat sakramental ini secara pribadi. Imam atau pelayan Sakramen sendiri, di samping memberikan absolusi, perlu memberikan silih atau denda dosa yang tepat. Ia juga perlu mengetahui sikap atau kecenderungan batin peniten. Untuk itu peniten, selain menyadari dosa yang telah diperbuat, menyesali dosa tersebut dan berniat untuk tidak melakukannya lagi, juga harus mengakukan dosadosa mereka. Paus menegaskan hal ini mengutip Konsili Trente, bahwa perlulah "berdasarkan ketetapan ilahi mengakui semua dan setiap dosa berat". 
Menurut Paus, Gereja memandang ada ikatan hakiki antara penilaian yang dipercayakan kepada imam dalam Sakramen ini dengan perlunya peniten menyebutkan dosa-dosa mereka, kecuali jika hal ini tidak dimungkinkan. Karena pengakuan utuh atas dosa-dosa berat berdasarkan ketetapan ilahi merupakan bagian konstitutif Sakramen ini, maka dispensasi, interpretasi, kebiasaan setempat, dan sebagainya berada di luar diskresi para imam. Otoritas Gereja yang berwenang hanya bisa menunjukkan kriteria yang membedakan antara ketidakmungkinan mengakukan dosa yang memang nyata di satu sisi, dan situasisituasi di mana ketidakmungkinan itu kabur sifatnya dan dapat diatasi di sisi lain. Berdasarkan hal tersebut, Paus memandang perlu merujuk kembali pada Hukum Kanonik, untuk menegaskan kesetiaan pada perayaan Sakramen yang dipercayakan oleh Kristus kepada Gereja setelah kebangkitan-Nya ini, dan demikian juga menegaskan buah-buahnya (bdk. Yoh 20:19-23). Teristimewa hal ini perlu berkenaan dengan ditinggalkannya pengakuan individual dan penggunaan “absolusi umum” secara keliru.

Setelah melalui konsultasi dengan Kongregasi untuk Ajaran Iman, Kongregasi untuk Ibadat Ilahi dan Disiplin Sakramen-sakramen, Dewan Kepausan untuk Teks-teks Legislatif, serta setelah mendengarkan pertimbangan para Kardinal yang bertugas di Kuria Roma, dan untuk meneguhkan ajaran Gereja tentang Sakramen Tobat dan Rekonsiliasi, Paus menetapkan sejumlah hal.

Pertama, tentang tugas para ordinaris (pemangku wewenang Gerejawi). Para ordinaris bertugas mengingatkan para pelayan Sakramen Tobat bahwa Hukum Gereja universal, sebagai penerapan Ajaran Gereja di bidang ini, telah menetapkan bahwa pengakuan individual dan utuh serta absolusi merupakan sarana biasa untuk memperdamaikan umat beriman yang menyadari dosa beratnya dengan Allah dan Gereja. Ketidakmungkinan fisik dan moral sajalah mengecualikan seseorang dari pengakuan semacam ini, dan pendamaian dapat diperoleh dengan sarana-sarana lain. Maka para pelayan Sakramen ini wajib memastikan bahwa pengakuan umat beriman didengarkan ketika diminta, dan mereka mendapatkan kesempatan untuk mengaku secara individual pada hari dan waktu yang cocok bagi mereka. Para imam sendiri, yang memiliki hak untuk melayani Sakramen Tobat, harus selalu menunjukkan diri siap sepenuh hati untuk melayani kapanpun umat beriman meminta secara wajar. Keengganan menyambut domba yang terluka, dan membawa mereka kembali ke kandang, menjadi tanda kurangnya kepekaan pastoral.

Kedua, para ordinaris lokal, dan para pastor paroki serta rektor gereja dan tempat ziarah, secara berkala haruslah memastikan bahwa telah dibuat jadwal yang sungguh tepat sehingga umat beriman mengakukan dosa mereka. Di tempattempat ibadat para pelayan pengakuan harus terlihat jelas pada jadwal yang sudah diumumkan, sesuai dengan peluang bagi para peniten untuk mengaku dosa, dan 
bahwa pengakuan secara khusus diadakan sebelum misa, bahkan pada saat misa jika ada imam lain yang bisa melayani, demi memenuhi kebutuhan umat beriman.

Ketiga, umat beriman wajib mengakukan dosa-dosa berat yang dilakukan setelah Baptis menurut jenis dan jumlahnya. Dosa-dosa itu harus disadari melalui pemeriksaan batin yang teliti, termasuk dosa-dosa yang belum secara langsung dilepaskan oleh kuasa kunci Gereja, atau yang belum diakukan dalam pengakuan individual. Maka praktik yang membatasi pengakuan hanya pada dakwaan dosa yang sifatnya umum (generic accusation of $\sin$ ) atau hanya pada satu atau dua dosa saja yang dinilai lebih penting, harus ditegur. Karena panggilan umat beriman kepada kekudusan, mereka didorong untuk mengakui juga dosa-dosa ringan.

Keempat, karena itu absolusi serentak terhadap sejumlah peniten tanpa didahului dengan pengakuan atas dosa-dosa, sebagaimana dibahas oleh Kan. 961 dalam Kitab Hukum Kanonik (KHK), haruslah dipahami dan dilaksanakan dengan tepat. Absolusi ini sifatnya kekecualian saja (“exceptional in character”), dan tidak dapat diberikan secara umum kecuali didesak oleh bahaya maut, serta tidak ada lagi waktu bagi imam atau para imam mendengarkan pengakuan para peniten secara individual. Alasannya dipandang serius jika dalam waktu yang tersedia jumlah peniten tidak sebanding dengan jumlah pelayan pengakuan, yang berakibat para peniten akan kehilangan rahmat sakramental atau Komuni suci untuk waktu yang lama bukan karena kesalahan mereka sendiri. Tetapi bukan keharusan memadai, jika pelayan pengakuan tidak cukup tersedia hanya karena jumlah peniten yang terlalu besar, seperti bisa terjadi pada pesta atau peziarahan besar. Alasan dipandang serius, jika misalnya dijumpai situasi yang secara objektif sungguh merupakan kekecualian, seperti terjadi di tanah misi atau pada komunitas umat yang terisolasi tempatnya, sehingga imam hanya bisa melakukan kunjungan sekali atau sebentar dalam kurun satu tahun, atau ketika terjadi perang atau kondisi-kondisi cuaca yang serupa.

Kelima, penilaian apakah terdapat kondisi-kondisi yang disyaratkan oleh Kan. 961 par.1,2 bukan merupakan wewenang para imam sebagai pelayan pengakuan, melainkan Uskup diosesan berdasarkan kriteria yang disepakati dengan para anggota lain dalam Konferensi Uskup. Kriteria ini haruslah mengungkapkan kesetiaan total pada kriteria fundamental yang terdapat dalam disiplin Gereja universal, yang dasarnya sendiri adalah syarat-syarat yang berasal dari Sakramen Tobat itu sendiri, sebagai suatu institusi ilahi.

Keenam, Konferensi-konferensi uskup sedunia harus secepat mungkin mengirimkan teks dan norma-norma yang mereka terbitkan sebagai penerapan atas Kan. 961 dalam terang Motu Proprio ini kepada Kongregasi untuk Ibadat Ilahi dan Disiplin Sakramen-sakramen. Hal ini akan menguatkan persekutuan di antara para Uskup sedunia dalam mendorong umat beriman di manapun untuk 
memperoleh rahmat dari sumber-sumber kerahiman ilahi yang mengalir tiada henti dalam Sakramen Pendamaian ini. Uskup diosesan juga perlu menyampaikan kepada Konferensi Uskup ada tidaknya kasus dengan alasan serius di wilayah yurisdiksi mereka, dan pada gilirannya Konferensi Uskup menyampaikan hal ini kepada Kongregasi dimaksud.

Ketujuh, terkait disposisi pribadi peniten, harus dicermati bahwa untuk memperoleh absolusi sakramental bagi banyak orang pada saat yang sama secara sah, umat beriman harus berada dalam disposisi yang memadai, dan pada saat yang sama harus berniat mengakukan dosa-dosa berat mereka secara individual, meski pada saat itu hal itu tidak mungkin dilakukan. Lalu, sejauh memungkinkan, termasuk dalam keadaan terdesak oleh bahaya kematian, harus ada seruan pendahuluan kepada umat beriman agar masing-masing dengan sadar menyatakan penyesalannya. Para peniten, yang berada dalam status habitual dosa serius dan tidak berniat mengubah situasi mereka itu, jelas tidak dapat menerima absolusi secara sah.

Kedelapan, kewajiban mengakukan dosa berat sekurang-kurangnya sekali setahun tetap berlaku, karena itu seseorang yang memiliki dosa berat, yang telah mendapatkan absolusi umum, harus datang ke pengakuan individual segera setelah terbuka kesempatan untuk melakukannya, sebelum menerima absolusi umum yang lain, kecuali ada sebab-sebab yang memadai.

Kesembilan, tempat dan ruang pengakuan yang cocok bagi perayaan Sakramen ini adalah Gereja atau kapel/ruang doa, meskipun perayaan di tempat lain dapat dibenarkan karena alasan pastoral. Ruang pengakuan diatur oleh norma-norma yang ditentukan oleh Konferensi Uskup, yang memastikan bahwa ruang tersebut berada di kawasan terbuka, dengan kisi-kisi terpasang, agar umat beriman dan pelayan pengakuan bisa memanfaatkannya secara bebas.

Selanjutnya, Kardinal Joseph Ratzinger, Prefek Kongregasi untuk Ajaran Iman kala itu, saat mempresentasikan Motu Proprio Misericordia Dei tanggal 2 Mei 2002, menyampaikan intervensi yang mengantar dan menjelaskan dokumen kepausan ini kepada publik (Ratzinger, 2002). Karena mengungkapkan semangat di balik Motu Proprio, intervensi ini juga perlu diketahui.

Pertama, Motu Proprio Misericordia Dei bermaksud menekankan hakikat personalistik Sakramen Tobat, yaitu bahwa dosa sepenuhnya bersifat personal, berkenaan dengan pribadi, maka penyembuhannya pun harus bersifat personal. Karena Allah tidak memperlakukan manusia secara kolektif belaka, melainkan memanggil masing-masing “dengan namanya sendiri”, maka panggilan-Nya untuk bangkit dari dosa juga ditujukan secara pribadi kepada setiap orang, dan hal itu dinyatakan dengan jelas dalam Sakramen Tobat. Maka pengakuan dan pengampunan yang personal menjadi bagian utuh dan konstitutif Sakramen ini. 
Kedua, seturut Konsili Trente, Gereja memahami bahwa kuasa mengampuni dosa, yang diberikan oleh Allah kepada para Rasul dan pengganti mereka, mensyaratkan penilaian yuridis (judgement). Penilaian ini harus dilakukan secara hati-hati, berdasar kuasa yang diberikan untuk "melepas atau mengikat, mempertahankan atau mengampuni”, yang mengandaikan dilaksanakannya diskresi mutlak atas setiap kasus secara individual. Di satu sisi mandat yang diberikan oleh Tuhan melampaui kuasa para Rasul dan Gereja, di sisi lain tugas mereka untuk membuat keputusan haruslah objektif dan adil, karenanya memiliki hakikat yang yuridis. Yurisdiksi merupakan bagian utuh dari Sakramen ini, dan mensyaratkan adanya suatu tata yuridis dalam Gereja demi terlaksananya kehendak Allah. Dalam hal ini Konsili Trente mengambil posisi berbeda dengan para Reformator, yang memandang Sakramen Tobat hanya menghasilkan tanda bahwa pengampunan telah diberikan melalui iman, karenanya tidak memberi dampak baru apapun selain pemberitahuan tentang apa yang telah senantiasa ada karena iman.

Ketiga, karena hakikatnya yang yuridis, Sakramen ini mengharuskan adanya pengakuan atas setiap dosa berat (mortal sin). Berbeda dengan Sakramen Baptis, Sakramen Tobat memiliki kuasa sakramental khusus, terkait langsung dengan Sakramen Imamat. Karena dalam Sakramen ini harus terdapat penilian yudisial, maka hakim harus mengetahui fakta yang terkait dengan kasus yang harus ia adili. Perlunya pengakuan pribadi dengan menyampaikan dosa-dosa, yang dimintakan ampunan dari Allah dan Gereja karena telah mencederai kesatuan kasih dengan Allah yang dianugerahkan dalam Baptis, implisit dalam aspek yuridis. Menurut Konsili Trente, berdasar hukum ilahi, diperlukan pengakuan atas semua dan setiap dosa berat. Maka Konsili mengajarkan bahwa kewajiban pengakuan ditetapkan oleh Tuhan sendiri dan bersifat konstitutif (mengikat) pada Sakramen ini, sehingga tidak ditentukan oleh sikap (disposisi) Gereja.

Keempat, Gereja tidak memiliki kuasa menggantikan pengakuan personal dengan absolusi umum. Keterbatasan kuasa ini diingatkan oleh Paus dalam Motu Proprio. Hanya dalam situasi yang perlu demi keselamatan akhir manusia, absolusi ini dapat diantisipasi dan pengakuan dapat dilakukan setelahnya, di saat yang memungkinkan. Inilah makna sesungguhnya dari absolusi “kolektif”. Gereja juga bertugas menentukan apakah situasi itu terjadi. Setelah beberapa dekade pengalaman tentang hal ini, dengan adanya aneka tafsir tentang makna perlunya hal ini, Paus memberikan batasan yang tegas yang harus diterapkan oleh para Uskup di wilayah mereka.

Kelima, Misericordia Dei tidak memberikan beban baru, tapi justru melindungi karakter hidup Kristiani yang sepenuhnya bersifat pribadi. Pengakuan pribadi atas dosa memang berat, karena menempatkan kebanggaan diri di titik 
terendah, dan mengharuskan orang berhadapan dengan kemiskinan dirinya. Tetapi dalam Sakramen Tobat, pengakuan ini diletakkan di hadapan kebaikan Allah yang penuh kerahiman, dalam semangat kepercayaan anak-anak Allah. Dengan cara ini, pengakuan dosa menjadi pengalaman pelepasan (an experience of deliverance). Beban masa lalu dilepaskan dari kita dan kita dijadikan muda kembali oleh jasa rahmat Allah yang setiap kali memberikan kemudaan sepenuhnya kepada hati manusia.

\section{REDISCOVERING THE RITE OF PENANCE: NILAI PERSONAL DAN EKLESIAL PERTOBATAN, SERTA FUNGSI KATEKETIS- MISTAGOGIS SAKRAMEN TOBAT}

Selanjutnya, 13 tahun setelah Misericordia Dei, Kongregasi untuk Ibadat Ilahi dan Disiplin Sakramen-sakramen menerbitkan dokumen dalam Jurnal Notitiae nomor 2015/2, dengan judul "Rediscovering the Rite of Penance" (Congregation, 2015). Dengan dokumen ini, Kongregasi bermaksud merefleksikan Ordo Paenitentiae, dengan memusatkan perhatian pada beberapa aspek teologis-liturgis beserta kandungan kateketis-mistagogis dari dinamika perayaan ritus itu sendiri, yang melibatkan baik peniten maupun pelayan pengakuan. Dengan refleksi ini diharapkan kita dapat menemukan kembali wajah Allah yang sejati dan menyerahkan diri penuh kepercayaan pada rencana kasihNya, sembari menemukan kembali wajah manusiawi kita sendiri.

Melihat strukturnya, dokumen ini terdiri dari 2 bagian. Pertama, bagian yang membahas penyesalan dan pertobatan hati peniten dan sikap yang diperlukan dari pelayan pengakuan. Kedua, bagian yang membahas dimensi mistatogis, atau bimbingan menuju hidup iman yang mendalam, yang diharapkan muncul dari dinamika pengakuan dosa. Bagian pertama mengangkat tema sentral Notitiae, sekaligus mendasari pembahasan bagian kedua, yang bersifat pendalaman.

Dokumen diawali dengan pembahasan tentang "hilangnya kesadaran akan dosa” yang dikonfirmasi oleh banyak uskup dari berbagai penjuru dunia selama kunjungan ad limina. Persoalan ini melanda umat beriman baik awam maupun imam. Akarnya adalah kebingungan, dan kurangnya pengakuan atas hakikat dosa individual beserta keinginan mengakukannya agar memperoleh pengampunan Allah. Keprihatinan ini sebenarnya telah muncul pada Paus Pius XII dan Paulus VI. Kini, Tahun Yubileum Kerahiman (2015-2016) merupakan saat tepat untuk memulihkan makna sejati dosa dalam terang Sakramen Pengampunan, yang dasarnya adalah dialektika antara misteri dosa manusia dan kerahiman Allah yang tanpa batas.

Untuk menemukan kembali nilai yang terkandung dalam Tata Perayaan Tobat, mula-mula dirujuk latar belakang teologis Sakramen Tobat dalam Praenotanda, yaitu untuk mengasihi Allah secara mendalam dan berkomitmen 
sepenuhnya pada-Nya, serta untuk diperdamaikan kembali dengan saudarasaudari kita. Lebih jauh, pengalaman sakramental mensyaratkan penerimaan atas undangan Yesus di awal perutusan-Nya, yaitu: "Saatnya telah genap dan Kerajaan Allah sudah dekat. Bertobatlah dan percayalah kepada Injil” (Mrk 1:15).

Berkenaan dengan sikap tobat, dirujuk Konsili Trente yang menggariskan empat unsur tobat. Tiga yang pertama berkenaan dengan peniten (penyesalan, pengakuan, denda), dan yang terakhir berkenaan dengan pelayan pengakuan (absolusi). Keempat unsur ini diangkat oleh Ordo Paenitentiae, dengan penekanan pada sikap tobat atau penyesalan pada peniten. Praenotanda menggunakan istilah "pertobatan hati mendalam" (inner conversion of heart, dengan model perumpamaan tentang anak yang hilang, yang memutuskan untuk kembali ke rumah bapanya dengan penyesalan hati dan pertobatan. Tanpa pertobatan (conversion, metanoia), buah-buah sakramental akan hilang karena "keaslian tobat tergantung pada hati yang penuh penyesalan”. Praenotanda sendiri menafsirkan penyesalan yang dimaksud oleh Konsili Trente secara biblis: "Karena pertobatan harus berdampak pada pribadi dari dalam sehingga terusmenerus meneranginya dan lama-kelamaan menjadikannya semakin serupa dengan Kristus”.

Selain menjadi salah satu unsur dasar sakramental, pertobatan hati sekaligus menyatukan semua tindakan peniten, karena setiap unsur terarah kepada pertobatan hati ini. "Pertobatan hati mendalam mencakup pula dukacita karena dosa dan niat menciptakan hidup baru. Pertobatan ini terungkap lewat pengakuan yang disampaikan kepada Gereja, denda yang pantas, serta perubahan hidup”. Karena itu pertobatan hati tidak boleh dipahami sebagai tindakan sesaat dan sekali itu dilakukan, tetapi sebagai keputusan tegas menjauhkan diri dari dosa untuk melangkah maju terus mengikuti Kristus dan bersahabat dengan-Nya. Tata urutan perayaan tobat mengungkapkan berbagai momen atau tahapan dalam perjalanan itu, yang tidak berakhir pada saat perayaan sakramental itu selesai, tetapi yang membentuk seluruh kehidupan peniten.

Dalam konteks ini berbagai perayaan tobat non-sakramental layak dihargai. Perayaan-perayaan ini bernilai penting sekali karena, seperti dikatakan dalam Praenotanda, "menghimpun umat Allah untuk mendengarkan pewartaan Sabda Allah. Sabda ini mengundang mereka ke dalam pertobatan dan pembaharuan hidup serta mewartakan kebebasan kita dari dosa melalui wafat dan kebangkitan Kristus”. Perayaan-perayaan ini ditempatkan sebelum dan setelah perayaan Sakramen Tobat, karena pertobatan hati mengandaikan kesadaran akan apa itu dosa, dan akan dosa-dosa yang telah diperbuat. Sabda Allah sendiri berperan amat besar dalam pertobatan St. Agustinus, seperti ia katakan: “Aku mengasihi-Mu, Tuhan. Engkau menggetarkan hatiku dengan sabda-Mu, dan 
engkau telah mengasihi aku”. Doa ini sekaligus mengungkapkan bahwa cinta itu sendiri merupakan jawaban terhadap cinta Allah yang penuh kerahiman.

Dengan pemahaman akan pentingnya pertobatan hati, baik dalam perayaan Sakramen Tobat maupun dalam hidup umat beriman, selanjutnya dokumen Kongregasi untuk Ibadat Ilahi dan Disiplin Sakramen-sakramen mengarahkan perhatian pada pelayan sakramen, yang "tidak boleh lupa untuk menjadi peniten yang mengalami sukacita pengampunan dalam Sakramen ini”. Dalam Tradisi katolik, pelayan Sakramen Tobat disebut Guru dan Hakim, untuk menunjukkan objektivitas hukum, sekaligus Bapa dan Dokter, untuk mengingatkan akan kebutuhan cintakasih pastoral (caritas pastoralis) pada peniten. Konsili Trente menegaskan bahwa imam melaksanakan fungsi penghapusan dosa "sebagai pelayan Kristus", dan menjalankan tugas itu dalam "pola tindakan yuridis” (ad instar actus iudicialis). Sementara itu Ordo Paenitentiae berbicara tentang Hakim dan Dokter ketika mengatakan: "Untuk menjalankan pelayanannya dengan tepat dan setia, pelayan pengakuan harus memahami kerusakan-kerusakan jiwa (the disorders of souls) dan memberikan obat yang tepat (the appropriate remedies) pada mereka. Ia harus menjalankan tugasnya sebagai hakim secara bijaksana”. "Pelayan pengakuan memenuhi fungsi kebapaan (a paternal function): ia menyingkapkan hati Bapa dan menunjukkan citra Kristus, Gembala yang Baik”. Menurut Misericordiae Vultus, Bulla Penetapan Yubileum Luarbiasa Kerahiman oleh Paus Fransiskus, 11 April 2015, ia adalah "saksi Kerahiman Allah kepada pendosa yang bertobat”.

Selanjutnya, berbagai refleksi di atas terwujud nyata dalam perayaan Sakramen itu sendiri, karena ritus dan doa mengantar peniten dan pelayan pengakuan ke dalam pengalaman Kerahiman Allah, sehingga setiap perayaan Sakramen Tobat merupakan "Yubileum Kerahiman”. Di sisi lain, terdapat aspekaspek lain yang belum tersentuh dalam refleksi di atas, namun penting juga untuk diperhatikan. Misalnya, dimensi rohani, disipliner dan pastoral yang terkait dengan perayaan Sakramen Tobat; termasuk pembinaan terus-menerus (on-going formation) bagi para klerus, juga pembinaan awal di seminari dan lembagalembaga pembinaan. Demikian pula ketaatan pada disiplin sekitar absolusi umum (bdk. KHK, Kan. 961-963), juga risiko terkait diskresi dan privasi, perlindungan atas anonimitas dan kerahasiaan, yang dewasa ini terancam oleh perekaman dan penyebaran isi pengakuan yang dapat dilakukan dengan mudah, dan jelas merupakan sakrilegi dan melanggar kesucian Sakramen (bdk. KHK, Kan. 983).

Sementara itu, bagian kedua dokumenmendalami lebih lanjut dimensi mistagogis dalam Ordo Paenitentiae. Secara khusus dan terinci, dokumen lebih merujuk pada Bab I, "Ritus untuk Pendamaian Para Peniten Secara Individual”. Di situ dibahas satu persatu langkah-langkah dalam ritus ini, mulai dari penerimaan peniten, pembacaan sabda Allah, pengakuan dosa-dosa dan 
pemberian denda dosa, doa tobat peniten, absolusi, serta seruan pujian dan pengutusan. Bagian ini tidak bermaksud memberikan pemahaman baru tentang Sakramen Tobat, tetapi terutama untuk mengupayakan perayaannya yang lebih otentik, dengan kesadaran bahwa dalam tindakan-tindakan peniten dan imam, melalui tata gerak dan kata-kata, rahmat pengampunan dikaruniakan. Karena "hati hendaknya selaras dengan ungkapannya” (mens concordet voci), maka Sakramen ini patut dirayakan dengan pantas. Bentuk ritual merupakan hal yang amat penting, karena dalam liturgi "kata-kata mendahului pendengaran, dan tindakan membentuk kehidupan”.

Sebelum masuk ke dalam pendalaman atas langkah-langkah ritual pada Bab I tersebut, dokumen lebih dulu mengingatkan akan dimensi eklesial Sakramen, yang tampak menonjol dalam Bab II, "Ritus untuk Pendamaian Sejumlah Peniten dengan Pengakuan dan Absolusi Individual”. Ditegaskan bahwa hakikat Sakramen Tobat yang sangat personal dalam kenyataannya terkait erat dengan dimensi eklesial, karena Sakramen ini merupakan tindakan yang mendamaikan peniten dengan Allah dan Gereja. Sebab Praenotanda mengingatkan: "Perayaan komunal (Sakramen Tobat) menunjukkan dengan lebih jelas hakikat tobat yang bersifat gerejawi”. Sementara Konsili Vatikan II menyatakan: "Pelayanan-pelayanan liturgis bukanlah fungsi-fungsi privat, melainkan perayaan-perayaan Gereja [...]. Maka pelayanan-pelayanan liturgis terkait dengan seluruh tubuh Gereja; pelayanan-pelayanan ini mewujudkan tubuh Gereja dan berdampak padanya”. Dengan Gambaran tentang dimensi-dimensi personal dan komunal Sakramen Tobat, maka pemahaman tentang makna Sakramen ini, yang dihayati dalam pelaksanaan ritus, akan semakin membimbing murid-murid Kristus untuk semakin menyempurnakan diri di dalam pengudusan.

\section{KESIMPULAN DAN SARAN}

Dari studi tentang Tata Perayaan Tobat melalui dokumen-dokumen Gereja di atas, tampak nilai penting Sakramen ini dalam kehidupan Gereja, khususnya bagi pembentukan hidup Kristiani setelah Baptis. Sakramen Tobat menjadi momen pembaruan diri terus-menerus bagi para murid Kristus dalam pengudusan dan penyempurnaan diri di hadapan kerahiman Bapa. Melalui pertobatan hati mendalam, murid Kristus diperdamaikan dan dipersatukan kembali dengan Allah setiap kali ia jatuh dalam dosa, yang hakikatnya adalah pengingkaran atas kasih Allah kepadanya. Melalui Sakramen Tobat, ia kembali ke dalam persekutuan Gereja yang hakikatnya adalah kudus. Di satu sisi, Sakramen Tobat memberikan rahmat pengampunan, di sisi lain juga menjadikan murid Kristus semakin rendah hati dan semakin masuk ke dalam hakikat persatuan dengan Allah dan sesama dalam Gereja, yang tidak lain dibangun atas dasar kasih dan kerahiman-Nya. 
Studi tentang Tata Perayaan Tobat ini sekaligus memberikan kesadaran yang lebih kuat tentang pentingnya menempatkan kembali Sakramen ini dalam kehidupan harian umat beriman, khususnya di tengah "krisis kesadaran akan dosa” sebagai ancaman terhadap persatuan manusia dengan Allah dan dengan sesamanya. Persoalan yang terjadi secara universal ini kiranya juga perlu disikapi dalam pastoral Gereja lokal, karena Sakramen Tobat sebagai anugerah dan harta rohani tak tergantikan dalam Gereja, bersama dengan Ekaristi dan sakramensakramen lainnya, dapat didayagunakan bagi pertumbuhan rohani umat beriman di zaman ini.

Sebelum Konsili Vatikan II, perhatian pada Sakramen Tobat sebenarnya sudah muncul. Paus Yohanes XXIII, yang mencanangkan diselenggarakan Konsili Vatikan II dan mengundang para uskup sedunia menghadirinya, telah mengungkapkannya setidaknya dalam 2 dokumen kepausannya. Pertama, dalam Ensiklik Paenitentiam Agere tentang kebutuhan akan praktik pertobatan batiniah dan lahiriah, yang diedarkan 1 Juli 1962, atau beberapa bulan sebelum Konsili Vatikan II dibuka (Yohanes XXIII, 1962). Kedua, dalam Ensiklik Sacerdotii Nostri Primordia tentang St. Yohanes Maria Vianney, yang diterbitkan 1 Agustus 1959, menyambut perayaan 100 tahun wafatnya “martir ruang Pengakuan” ini tanggal 4 Agustus 1959. Pada Ensiklik ini St. Yohanes Maria Vianney ditampilkan sebagai figur penting dalam pelayanan Sakramen Tobat sepanjang sejarah Gereja, yang layak diteladani oleh para imam di seluruh dunia (Yohanes XXIII, 1959).

Selanjutnya, amanat Konsili Vatikan II, agar “Upacara dan rumus untuk Sakramen Tobat hendaknya ditinjau kembali sedemikian rupa, sehingga hakekat dan buah Sakramen terungkap secara lebih jelas” (SC, 72, tahun 1962), mengungkapkan kehendak Gereja untuk menghadirkan Sakramen Tobat secara baru bagi umat. Ordo Paenitentiae (1974) menampilkan pembaruan itu di satu sisi, dan kesetiaan pada warisan Gereja sepanjang masa, sebagaimana ditegaskan oleh Konsili Trente (1545-1563) tentang 4 unsur hakiki Sakramen Tobat, yaitu penyesalan, pengakuan dan silih atau denda oleh peniten serta absolusi oleh imam, di sisi lain. Sinode Uskup tahun tentang rekonsiliasi dan tobat dalam perutusan Gereja dewasa ini tahun 1983, disusul dengan Seruan Apostolik oleh Paus Yohanes Paulus II Reconciliatio et Paenitentia tahun 1984, menjadi momentum bagi Gereja untuk menyadari tantangan zaman yang dihadapinya berkenaan dengan "krisis kesadaran akan dosa”. Kini, pada awal Milenium III, mulai terlihat penerimaan Yang lebih luas akan Sakramen ini pada umat beriman, termasuk kaum muda.

Dua dokumen Gereja universal, Misericordia Dei oleh Paus Yohanes Paulus II tahun 2002 dan "Rediscovering The Rite of Penance” oleh Kongregasi untuk Ibadat Ilahi dan Disiplin Sakramen-sakramen tahun 2015 turut 
memperdalam makna penting sakramen ini, baik dari segi penghayatan personal bagi pertumbuhan pribadi setiap umat beriman maupun secara komunal dalam Gereja. Di satu sisi, penekanan tentang aspek peraturan atau disipliner dalam Motu Proprio Misericordia Dei telah mengingatkan kembali pentingnya penerapan Sakramen Tobat secara tepat sesuai maksud Ordo Paenitentiae dan Tradisi Gereja, yang mengutamakan dimensi personalistik Sakramen ini. Di sisi lain, Gereja disadarkan kembali tentang makna penting kedudukan sakramen ini bagi pengembangan pastoral umat beriman, entah melalui Perayaan Ibadat-ibadat Tobat yang berdimensi komunal, atau melalui kekayaan mistagogisnya, ketika Sakramen ini serta dimensi pertobatan dan kerahiman Allah sungguh mewarnai kehidupan Gereja sehari-hari.

Jika ditarik ke tataran pastoral Gereja lokal, kiranya dapat diajukan saran tentang perlunya menempatkan kembali Sakramen Tobat sebagai unsur penting bagi pembentukan hidup rohani umat beriman setelah Baptis, bersama dengan Sakramen Ekaristi. Dimensi formasio kiranya merupakan dimensi mendasar dalam Eklesiologi Persekutuan yang dibangun atas dasar prinsip Kemuridan. Dalam Eklesiologi semacam ini, Sakramen Tobat menjadi sarana hakiki bagi setiap murid Kristus untuk dari hari ke hari kian menyatukan diri dengan Kristus Sang Guru, yang telah wafat dan bangkit bagi keselamatannya. Melalui pembentukan kemuridan lewat Sakramen Tobat, bersama dengan Sakramen Ekaristi serta sakramen-sakramen lainnya, persekutuan dapat sepenuhnya dibangun dan ditumbuhkan, baik dengan Allah maupun dengan sesama. Maka Sakramen Tobat, didukung oleh semangat tobat komunal yang mewarnai iklim persekutuan Gereja lokal, oleh para murid Kristus perlu ditempatkan sebagai “sakramen formasio”, “sakramen mistagogi” atau "sakramen pembentukan” bagi hidup rohani dan kehidupan iman.

Dalam kehidupan Gereja Keuskupan Surabaya selama ini, rupanya Sakramen Tobat sebagai “sakramen mistagogi”, “sakramen pembentukan” atau "sakramen formasio" masih menjadi "harta terpendam”, belum sungguh disadari dan didalami makna penting dan dayagunanya. Dalam kondisi itu, tahun 2020 sebagai Tahun Pertobatan bagi seluruh Keuskupan dalam rangka Ardas 20202030 dapat dijadikan momentum untuk menempatkan Sakramen Tobat sebagai Sakramen Mistagogi dan Formasio seluruh umat, dilanjutkan dengan pembiasaannya sepanjang Tahun Kemuridan, tahun 2021-2024. Di antara para imam dan tenaga pastoral, perhatian terhadap hal ini dapat ditumbuhkan dengan kegiatan-kegiatan studi, retret, rekoleksi dan pendalaman lainnya. Di antara umat dapat diadakan berbagai bentuk kegiatan katekese dan pastoral serta pengembangan bentuk ibadat-ibadat yang mendukung ke arah tobat.

Namun lebih jauh, jika melihat realitas pastoral di Keuskupan, tampaknya perlu diupayakan pendalaman lebih lanjut tentang tantangan-tantangan berkenaan 
dengan upaya menempatkan Sakramen Tobat ini sebagai "sakramen formasio" atau "sakramen pembentukan" hidup iman umat. Ditengarai bahwa selama ini gairah umat untuk menyambut Sakramen Tobat tidak seantusias seperti dibandingkan dengan penerimaan mereka terhadap Sakramen Ekaristi, misalnya, entah karena kurangnya katekese di bidang ini, ataupun karena segi-segi psikologis berkenaan dengan pengalaman dosa dan mengaku dosa. Belum lagi ditambah dengan situasi zaman yang membuat orang merasa asing dengan hal-hal yang bersifat rohani hingga enggan untuk memasuki atau mengolahnya. Apalagi jika itu menyangkut dosa dan hal-hal batiniah yang penuh misteri di kedalaman hati manusia.

Ilmu-ilmu yang berkembang sekarang ini, misalnya di bidang psikologi, yang bersifat empiris, barangkali juga turut mengaburkan arti rohani dari unsurunsur antropologis yang mendasar dalam Sakramen Tobat, misalnya berkenaan dengan arti “dosa”, yang bisa tereduksi sekedar sebagai "kesalahan manusiawi” tanpa melibatkan dimensi moral. Atau berkenaan dengan arti “penyesalan” yang sesungguhnya adalah rasa derita yang muncul dari perbuatan dosa pribadi atau dosa social, dengan kesadaran akan kejahatan dan keburukan yang diakibatkannya, namun oleh pengaruh ilmu psikologi atau konseling menjadi sekedar sarana yang boleh diabaikan jika tidak membuat seseorang merasa nyaman.

Mengingat pentingnya pokok persoalan ini bagi "usaha pengudusan terusmenerus”, maka upaya-upaya pastoral, termasuk bimbingan yang lebih personal untuk mendidik hati nurani dan melakukan pembedaan roh atau discermnet perlu mulai serius dipikirkan. Upaya-upaya itu perlu disertai dengan upaya-upaya studi atau kajian yang mendukung, dengan tetap berpijak dari pengalaman sehari-hari umat dalam bergulat menuju kekudusan dengan bantuan-bantuan pastoral, rohani dan sakramental. Tentu dengan tidak melupakan dimensi ilahi, yaitu kekuatan rahmat Allah, sebagai unsur utama yang mengiringi upaya-upaya manusia. 


\section{DAFTAR PUSTAKA}

Congregation for Divine Worship and the Discipline of the Sacraments., 2015. "Rediscovering the Rite of Penance”. Notitiae 2015/2. Diunduh dari http://www.vatican.va/roman_curia/congregations/ccdds/documents/rc_co n_ccdds_notitiae-2015-quaderno-penitenza_en.html

Dallen, James., 1991. The Reconciling Community: The Rite of Penance, Minnesota: The Liturgical Press.

Keuskupan Surabaya., 2019. Arah Dasar Keuskupan Surabaya Tahun 2020-2030. Paulus II, Yohanes., 2002. Apostolic Letter in the Form of Motu Proprio Misericordia Dei on Certain Aspects of the Celebration of the Sacrament of Penance. Diunduh dari http://www.vatican.va/content/john-paulii/en/motu_proprio/documents/hf_jp-ii_motuproprio_20020502_misericordia-dei.html

Ratzinger, Joseph Kardinal, 2002. Presentation of the Apostolic Letter in the Form of Motu Proprio Misericordia Dei. Congregation for the Doctrine of the Faith. Diunduh dari http://www.vatican.va/roman_curia/congregations/cfaith/documents/rc_co n_cfaith_doc_20020502_ratzinger-penance_en.html

Sacra Congregatio Pro Culto Divino., 1974. Ordo Paenitentiae. Editio Typica. Typis Polyglottis Vaticanis.

Yohanes XXIII, 1962. Paenitentiam Agere. Ensiklik tentang Kebutuhan akan Praktik Pertobatan Batiniah dan Lahiriah. Diunduh dari http://www.vatican.va/content/john-xxiii/en/encyclicals/documents/hf_jxxiii_enc_01071962_paenitentiam.html ., 1959. Sacerdotii Nostri Primordia. Ensiklik tentang St. Yohanes Vianney. Diunduh dari http://www.vatican.va/content/johnxxiii/en/encyclicals/documents/hf_j-xxiii_enc_19590801_sacerdotii.html 